\title{
Alat Pendeteksi Dan Monitoring Kematangan Tape
}

\author{
Karina Djunaidi ${ }^{1}$; Hendra Jatnika ${ }^{2}$; Rahma Farah Ningrum ${ }^{3}$; Wali Syahputro Cahoyo Kabidoyo ${ }^{4}$ \\ 1, 2,3,4Program Studi Teknik Informatika, Sekolah Tinggi Teknik PLN \\ ${ }^{1}$ karina@sttpln.ac.id \\ ${ }^{2}$ h.jatnika@sttpln.ac.id \\ ${ }^{3}$ rahmafarah@sttpln.ac.id \\ ${ }^{4}$ wali.syahputro@gmail.com
}

\begin{abstract}
Cassava tape is a food made from the results of fermentation involving yeast in the manufacturing process. Detection of temperature, humidity, and weight is done to see the fermentation of yeast in cassava to tape. The purpose of this study is to design a device for detecting automatically whether tape has reached its best condition using the Dht11 sensor and load cell sensor, with the Arduino Uno as the microcontroller for the ripe process on cassava tape. From this study, the results showed that cassava tape which was fermented at 30-35 degrees Celsius in 24 hours was said to be ripe. This was marked by the changes in texture, aroma, color, and taste of the cassava tape. So it can be concluded that tape fermentation using tape detection devices can improve the quality of the tape produced.
\end{abstract}

Keywords: Tape, detection monitoring of tape ripe, arduino uno

\begin{abstract}
ABSTRAK
Tape singkong merupakan makanan yang terbuat dari hasil fermentasi dengan melibatkan ragi di dalam proses pembuatannya. Pendeteksian pada suhu, kelembaban dan berat dilakukan untuk melihat fermentasi ragi pada singkong hingga menjadi tape. Tujuan dari penelitian ini adalah merancang sebuah alat pendeteksi kematangan tape secara otomatis menggunakan sensor Dht11 dan sensor load cell, dengan microcontroler arduino Uno untuk proses kematangan pada tape singkong. Dari penelitian ini diperoleh hasil yang menunjukan bahwa tape singkong yang difermentasi pada suhu 30-35 derajat Celcius dalam 24 jam sudah bisa dikatakan matang, hal ini ditandainya dengan tekstur, aroma, warna dan rasa pada tape singkong yang berubah. Sehingga dapat disimpulkan bahwa fermentasi tape dengan menggunakan alat pendeteksi kematangan tape dapat meningkatkan kualitas tape yang dihasilkan.
\end{abstract}

Kata kunci: Tape, alat pendeteksi monitoring kematangan tape, Arduino uno 


\section{PENDAHULUAN}

Tape merupakan salah satu makanan tradisional Indonesia yang dihasilkan dari proses fermentasi bahan pangan berkarbohidrat atau sumber pati, yang melibatkan ragi di dalam proses pembuatannya [1] Dalam proses fermentasi tape, digunakan beberapa jenis mikroorganisme seperti Saccharomyces Cerevisiae, Rhizopus oryzae, Endomycopsis burtonii, Mucor sp., Candida utilis, Saccharomycopsis fibuligera, Pediococcus, dsb sp [2].

Pembuatan tape tidak hanya berbahan baku singkong maupun ketan. Tape juga dapat dibuat dari ubi jalar, kandungan karbohidrat ubi jalar relatif tinggi yaitu sebesar 16-35\% per berat basah atau 8090\% per berat kering, sehingga ubi jalar layak dibuat menjadi tape [3]. Prinsip pembuatan tape ubi jalar sama dengan pembuatan tape ketan atau tape singkong.

Fermentasi adalah suatu proses perubahan kimia pada substrat organik sebgagai akibat aktivitas enzim yang dihasilkan oleh mikroba, namun dalam beberapa hal fermentasi dapat berlangsung tanpa malibatkan mikroorganisme. Mikroorganisme pada proses fermentasi ini umumnya adalah bakteri asam laktat, 9 bakteri asam asetat yaitu bakteri yang mampu mengubah zat gula dalam bahan menjadi asam, alkohol, dan karbondioksida. Terjadinya fermentasi ini maka bahan mengalami perubahan rasa, aroma, tekstur dan warna [4].

Pada Proses fermentasi tersebut biasanya memerlukan waktu yang lama untuk menyebabkan tekstur tape menjadi lunak dan empuk [5]. Sehingga butuh waktu yang tepat untuk mengetahui tape singkong matang secara baik. Secara konvensional, proses fermentasi tape, para pengrajin tape memprediksikan kematangan tape dengan menghitung hari dari mulai proses dimulai. Pengrajin tape tidak mengetahui dengan pasti bagaimana proses fermentasi berlangsung, sehingga untuk mengetahui proses terjadi para pengrajin tape harus memeriksa secara langsung dengan membuka atau menutup wadah fermentasi. Hal ini menyebabkan terganggunya proses fermentasi tape sehingga memerlukan waktu yang semakin lama yaitu 3-5 hari sehingga mengakibatkan produksi tape yang dihasilkan tidak maksimal dan menyebabkan kerugian untuk pengrajin tape.

Oleh karena itu dirancang suatu alat pendeteksi dan monitoring dengan menggunakan sensor yang dipasang ke Arduino Uno untuk mengatasi masalah tersebut. Sensor yang digunakan adalah sensor suhu, kelembapan dan berat sebagai penentu kematangan tape [6],[7] [8]. Status dan hasil dari fermentasi akan dikirimkan sensor yang dihubungkan ke Arduino yang terpasang pada wadah fermentasi. dan ditampilkan ke aplikasi monitoring kematangan tape. Apabila proses fermentasi telah mencapai suhu, kelembapan dan berat tertentu, maka wadah fermentasi akan secara otomatis membuka tutup wadah untuk menstabilkan suhu. Hal ini menandakan proses fermentasi telah selesai dan tape telah matang.

\section{METODE PENELITIAN}

\section{A. Perancangan Alat}

Merancang alat dengan menggunakan komponen-komponen yang dibutuhkan seperti terlihat pada gambar 1. dibawah ini: 


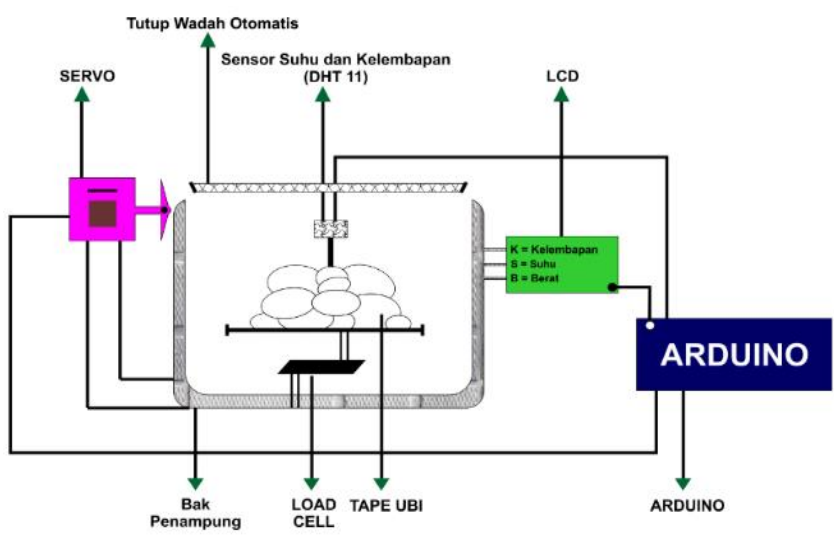

Gambar 1. Skema Perancangan Alat

\section{1) Load cell}

Dalam prototype, load cell berfungsi sebagai timbangan berat untuk mendeteksi berat yang bertambah pada saat tape ubi di fermentasi dan sebagai penentu kematangan seperti diperlihatkan pada gambar 2 dibawah ini.

Komunikasi pin antara load cell dan Arduino dapat digambarkan dalam tabel berikut:

Tabel 1. Komunikasi Pin load cell dan Arduino Uno

\begin{tabular}{|c|c|}
\hline Arduino & Sensor load cell \\
\hline GND & GND \\
\hline PIN 4 & DT \\
\hline PIN 5 & SCK \\
\hline 5V & VCC \\
\hline
\end{tabular}

2) Sensor suhu dan kelembaban (DHT11)

Sensor suhu dan kelembaban (DHT 11), berfungsi sebagai pendeteksi suhu dan kelembaban pada saat tape Singkong berfermentasi. Komunikasi pin antara DHT11 dan Arduino Uno dapat digambarkan dalam tabel berikut:

Tabel 2. Komunikasi Pin sensor suhu dan kelembaban (DHT11) dan Arduino

\begin{tabular}{|l|l|}
\hline Arduino & Sensor Suhu Dan Kelembaban (DHT11) \\
\hline GND & GND \\
\hline 5V & VCC \\
\hline PIN 7 & DATA \\
\hline
\end{tabular}

\section{3) LCD (Liquid Crystal Display)}

LCD berfungsi sebagai menampilkan data deteksi suhu, kelembaban dan berat ketika fermentasi tape ubi sedang berlansung. Komunikasi pin antara LCD dan Arduino tersebut dapat digambarkan dalam tabel berikut:

Tabel 3. Komunikasi Pin LCD dan Arduino Uno

\begin{tabular}{|l|l|}
\hline Arduino & LCD \\
\hline GND & GND \\
\hline $5 \mathrm{~V}$ & VCC \\
\hline A4 & SDA \\
\hline A5 & SCL \\
\hline
\end{tabular}




\section{4) Modul WiFi}

Modul wifi berfungsi sebagai menampilakan data deteksi suhu, kelembaban dan berat ketika fermentasi tape ubi sedang berlangsung. Komunikasi pin antara kedua perangkat tersebut dapat digambarkan dalam tabel berikut:

Tabel 4. Komunikasi Pin Modul WiFi dan Arduino Uno

\begin{tabular}{|l|l|}
\hline Arduino & Modul WiFI \\
\hline $3.3 \mathrm{~V}$ & VCC \\
\hline $3.3 \mathrm{~V}$ & CH_PD \\
\hline GND & GND \\
\hline 7 & UTXD \\
\hline 8 & URXD \\
\hline
\end{tabular}

\section{5) Servo}

Servo berfungsi sebagai penggerak tutup wadah fermentasi secara otomatis, sehingga apabila suhu di dalam wadah melebihi tingkat yang ditentukan maka tutup akan membuka otomatis dan menstabilkan suhu kembali. Komunikasi antara pin kedua perangkat yaitu servo dan Arduino Uno digambarkan dalam table berikut:

Tabel 5. Komunikasi Pin Servo Motor dan Arduino Uno

\begin{tabular}{|l|l|}
\hline Arduino Uno & Servo \\
\hline PIN 9 & Data \\
\hline GND & GND \\
\hline VCC 5 & Sumber Tegangan \\
\hline
\end{tabular}

\section{B. Cara Kerja Alat}

1. Kinerja alat dimulai dengan inisialisasi IP pada Arduino IDE agar terhubung dengan web

2. Web akan memonitoring hasil kerja dari mikrokontroler Arduino Uno

3. Modul wifi melalui Acces Point (wireless) akan menjebatani antara aplikasi di perangkat web dan alat

4. Ada 3 sensor yang di gunakan untuk mendeteksi kematangan pada tape singkong

a. Sensor suhu untuk mendeteksi suhu pada saat fermentasi

b. Sensor kelembaban untuk mendeteksi kelembaban pada saat fermentasi

c. Sensor berat (loadcell) untuk mendeteksi berat yang akan bertambah pada saat fermentasi.

5. Jika suhu melebihi $40^{\circ}$ lebih maka tutup wadah akan terbuka otomatis untuk menetralkan suhu pada wadah fermentasi.

6. Jika suhu $>30^{\circ}$ maka akan mengirim notif fermentasi berhasil selama proses 24 jam lamanya

7. Jika suhu $>22^{0}$ maka akan menirim notif fermentasi sedang berlansung berhasil selama proses 24 jam lamanya

8. Jika suhu $<22^{0}$ maka akan mengirim notif fermentasi gagal berhasil selama proses 24 jam lamanya 
Berikut merupakan diagram alir kerja alat:

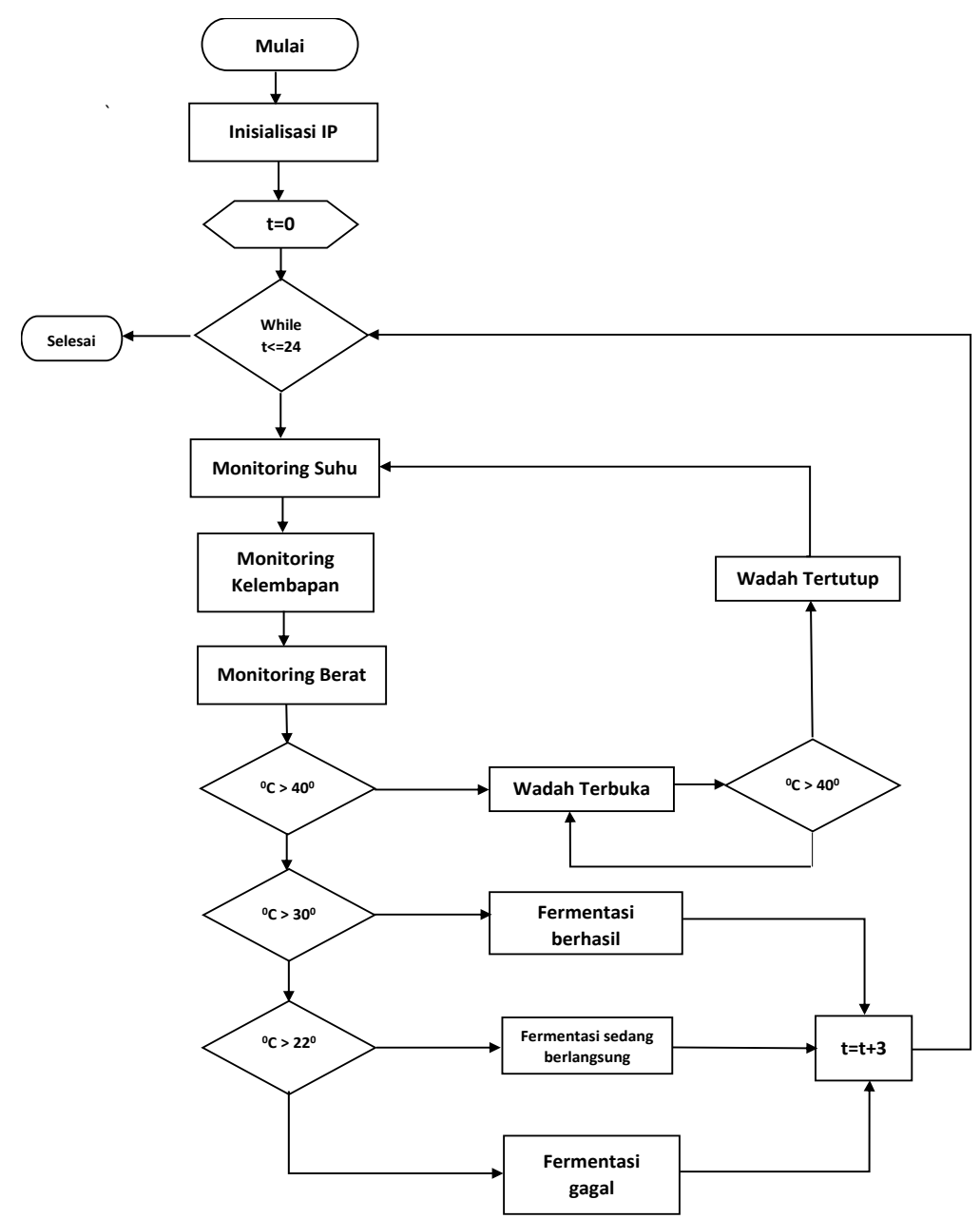

Gambar 2. Diagram Kerja Alat

Tahap selanjutnya mikrokontroler akan mengirimkan data ke perangkat web dan dapat diamati oleh pengrajin.

\section{Perancangan Media Fermentasi}

Perancangan media fermentasi menggunakan singkong dan ragi sebagai bahan utama untuk di fermentasi menjadi tape singkong.

1. singkong sebanyak $1 \mathrm{~kg}$

2. ragi sebanyak 1 butir

3. wadah fermentasi pendeteksi kematangan otomatis

\section{HASIL DAN PEMBAHASAN}

Perangkat keras yang digunakan pada penelitian ini berupa hasil perancangan sensor suhu dan kelembaban (dht11), load cell, servo dan perancangan Arduino. Berikut akan dijelaskan hasil dan cara kerjanya: 


\section{A. Sensor Suhu dan Kelembaban (Dht11)}

Pada alat ini menggunakan sensor suhu dan kelembaban (Dht11) yang dipasang didalam wadah fermentasi tape singkong. Sensor tersebut berfungsi sebagai pendeteksi suhu dan kelembaban pada saat tape singkong di fermentasi.

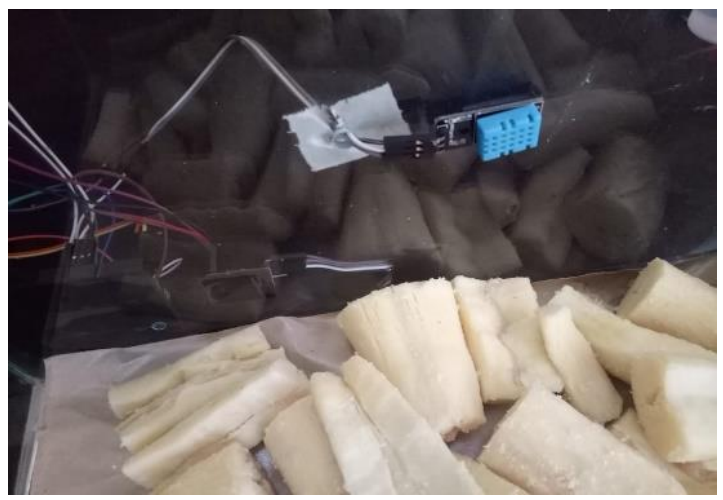

Gambar 3. Sensor DHT11

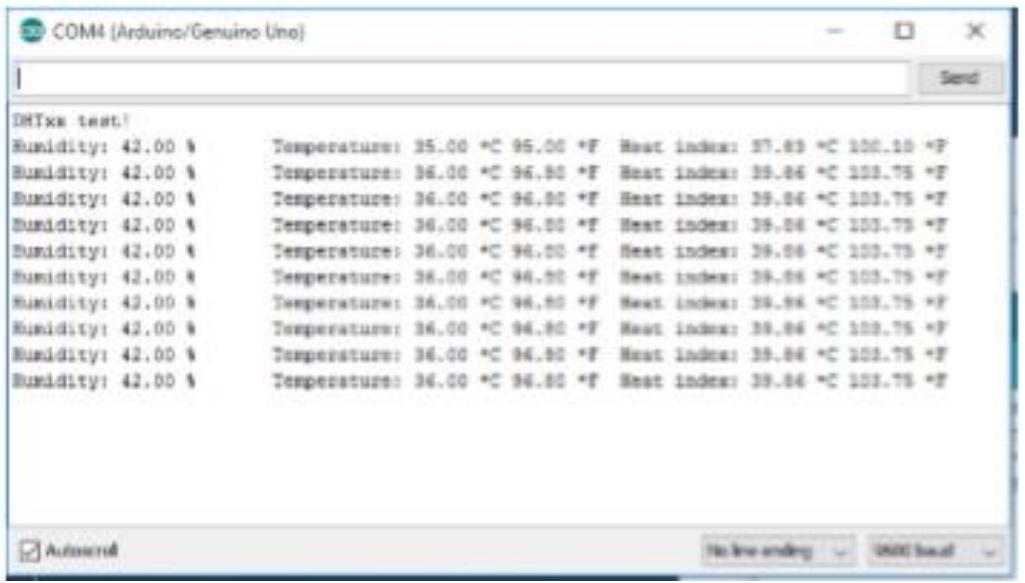

Gambar 4. Hasil kalibrasi Sensor DHT11

Gambar diatas menjelaskan tentang pembacaan kalibrasi sensor, variabel yang digunakan untuk kebutuhan monitoring adalah suhu dan kelembaban. Pembacaan sensor yang sesuai jika nilai kalibrasi bernilai konstan.

\section{B. Sensor Berat Load Cell}

Sensor berat (load cell) diletakan didalam wadah fermntasi. Sensor tersebut berfungsi sebagai parameter kematangan pada saat tape singkong difermentasi.

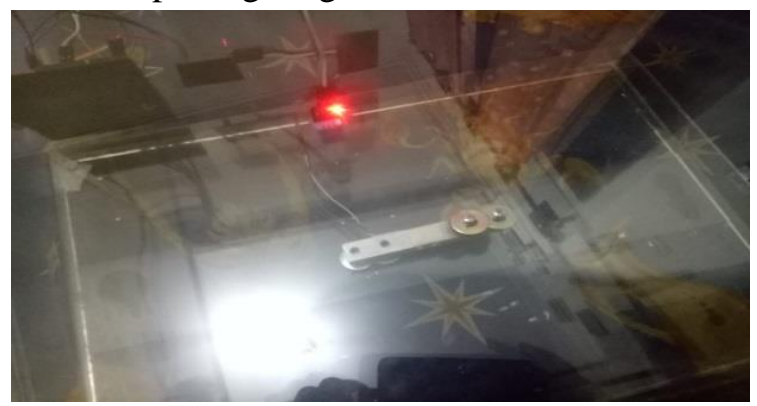

Gambar 5. Sensor Berat (Load Cell) 


\section{Servo Motor}

Servo motor di letakan di luar wadah, di bagian tutup wadah fermentasi, servo motor tersebut berfungsi sebagai untuk mengangkat wadah apabila suhu dalam wadah melebihi $40^{\circ} \mathrm{C}$.

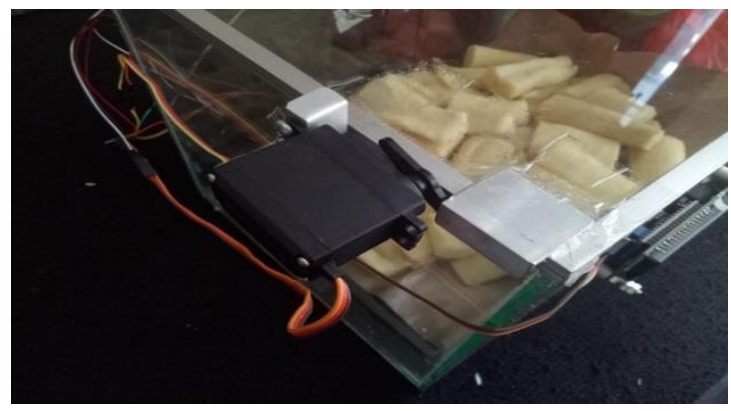

Gambar 6. Servo Motor pada wadah fermentasi

\section{LCD}

LCD diletakan didepan wadah fermentasi, LCD tersebut berfungsi sebagai pemberi informasi secara langsung selama proses fermentasi sedang berlangsung.

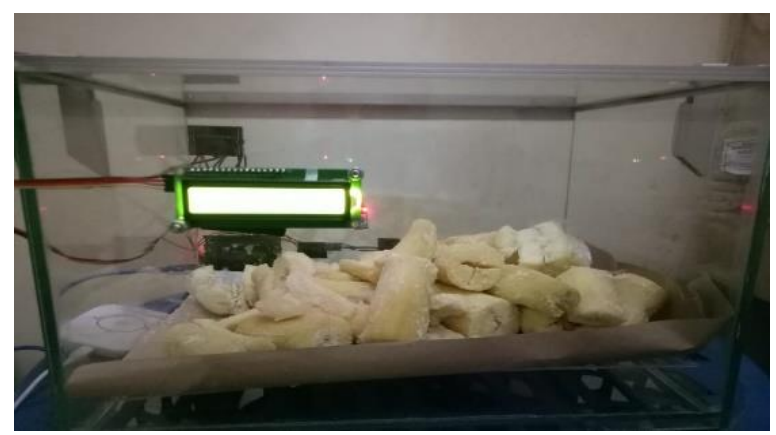

Gambar 7. LCD pada wadah Fermentasi

\section{E. Rangkaian Arduino}

Arduino yang digunakan pada penelitian ini adalah Arduino UNO. Arduino UNO digunakan untuk memprogram pembacaan sensor DHT11 yaitu sensor suhu dan kelembaban, sensor Berat (loadcell), servo motor, modul wifi, dan data sensor untuk kebutuhan monitoring. Berikut adalah gambar dari rangkaian sistem Arduino Uno.

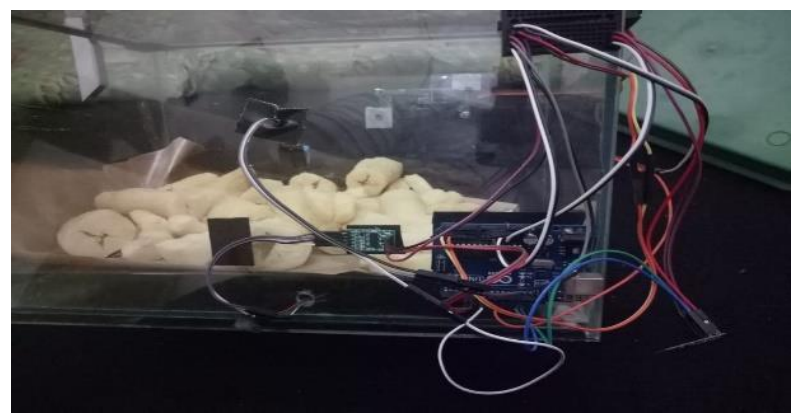

Gambar 8. Rangkaian Arduino

Setelah alat selesai dirancang, dilakukan proses fermentasi tape dan pengamatan terhadap proses berjalannya proses tersebut, Observasi ini dilakukan dengan pembuatan tape singkong selama 24 jam dengan menggunakan alat pendeteksi kematangan pada tape. Mekanisme dalam pengujian ini adalah 
dengan mengecek suhu, kelembaban dan berat pada saat fermentasi sedang berlangsung selama 24 jam.

\section{F. Hasil Pengujian}

a) Suhu

Pengamatan suhu fermentasi dilakukan selama 24 jam dengan interval 3 jam setiap pengamatan. pengamatan pertama dilakukan pada proses fermentasi suhu $30^{\circ} \mathrm{C}$ kemudian dilanjutkan dengan pengamatan 3 jam selanjutnya suhu $32^{\circ} \mathrm{C}$ kemudian sampai selama 24 jam fermentasi berlansung yaitu $33^{\circ} \mathrm{C}$

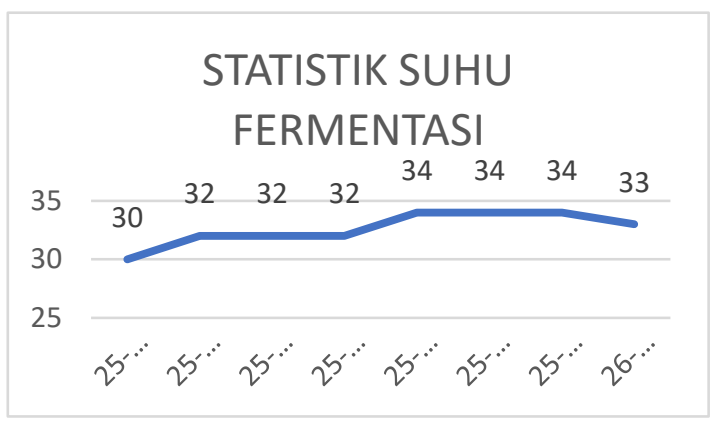

Gambar 9. Statistik Suhu Fermentasi

b) Kelembaban

Pengamatan Kelembaban fermentasi dilakukan selama 24 jam dengan interval 3 jam setiap pengamatan. pengamatan pertama di lakukan pada proses fermentasi kelembaban $56 \%$ kemudian dilanjutkan dengan pengamatan 3 jam selanjutnya Kelembaban $70 \%$ kemudian sampai selama 24 jam fermentasi berlansung yaitu 95\%. Pada hasil pengamatan kelembaban, terlihat peningkatan yang terjadi pada saat fermentasi selama 24 jam, kelembaban yang meningkat dari 56\% - 95\% kelembaban ini terjadi dikarenakan suhu yang meningkat pada saat fermentasi terjadi selama 24 jam, sehingga terjadi embun pada wadah fermentasi.

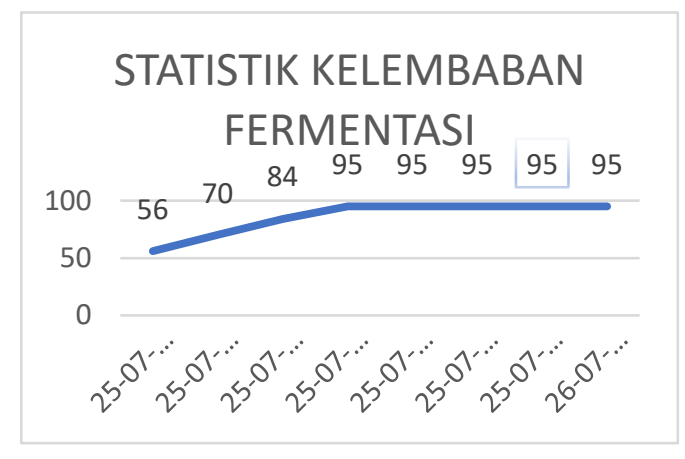

Gambar 10. Statistik Kelembaban Fermentasi

c) Berat

Pengamatan Berat fermentasi dilakukan selama 24 jam dengan interval 3 jam setiap pengamatan.pengamatan pertama di lakukan pada proses fermentasi Berat 1587 gr kemudian dilanjutkan dengan pengamatan 3 jam selanjutnya Berat 1550gr kemudian sampai selama 24 jam fermentasi berlansung yaitu 1323gr. Pada hasil pengamatan Berat,terlihat penurunan berat yang terjadi pada saat fermentasi selama 24 jam, penurunan berat dari $1587 \mathrm{gr}$ - 1323gr selama 24 jam terjadi di karenakan adanya pelepasan zat pati pada saat singkong sedang di fermentasi, 
penurunan berat tidak banyak hanya saja 100gr samapai $200 \mathrm{gr}$, tergantung berapa banyak singkong yang akan difermentasi.

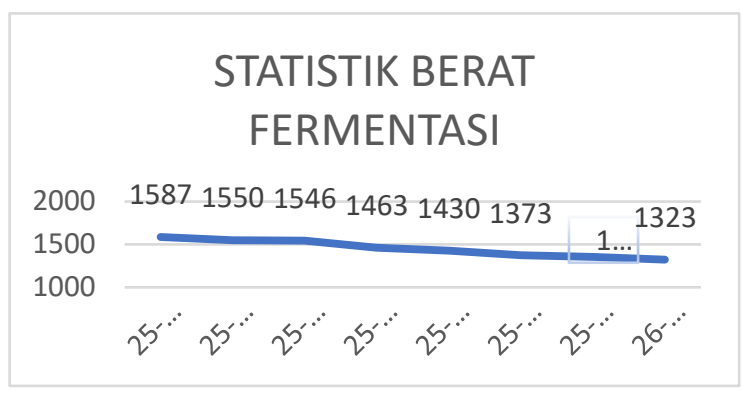

Gambar 11. Statistik Berat Fermentasi

\section{KESIMPULAN DAN SARAN}

Berdasarkan hasil penelitian dan pembahasan yang telah dilakukan dapat diambil beberapa kesimpulan, antara lain: Dengan menggunakan alat pendeteksi dan monitoring kematangan tape diketahui bahwa tingkat kematangan tape singkong yang baik berada pada suhu $30^{\circ} \mathrm{C}-35^{\circ} \mathrm{C}$. Sedangkan untuk berat singkong saat fermentasi hingga menjadi tape akan berkurang, hal ini disebabkan oleh adanya pelepasan zat pati saat proses fermentasi berlangsung. Sehingga dengan menggunakan alat pendeteksi dan monitoring kematangan tape dapat membantu para pengrajin menentukan kematangan tape singkong dengan cepat sehingga membantu meningkatkan dalam produksi tape singkong dengan pemantauan fermentasi berdasarkan suhu, kelembaban dan berat pada saat proses fermentasi.

Adapun saran dari hasil penelitian ini adalah alat pendeteksi dan monitoring kematangan tape dapat dikembangkan untuk semua jenis makanan yang melalui proses fermentasi.

\section{DAFTAR PUSTAKA}

[1] M. Astawan and M. Astawan, "Teknologi Pengolahan Pangan Nabati Tepat Guna. Bogor," Akademika Presssiado, 1991.

[2] I. Ganjar, "Tapai from Cassava and Sereals," First International Symposium and Workshop on Insight into the World of Indigenous Fermented Foods for Technology Development and Food Safety, pp. 1-10, 2003.

[3] T. Susanto and B. Saneto, Teknologi Pengolahan Hasil Pertanian, Surabaya: Bina Ilmu, 1994.

[4] E. Novary, Penanganan dan Pengolahan Sayuran Segar, Jakarta: Penebar Swadaya, 1999.

[5] I. P. Aminah, "Mutu Fisik, Kadar Serat dan Sifat Organoleptik Nata de Cassava Berdasarkan Lama Fermentasi," Jurnal Pangan dan Gizi, pp. 29-38, 2013.

[6] M. Adiptya and H. Wibawanto, "Sistem Pengamatan Suhu dan Kelembaban Pada Rumah Berbasis Mikrokontroller ATmega8," Jurnal Teknik Elektr, pp. 15-17, 2013.

[7] M. Asnawi, "Karateristik tape ubi kayu (manihot utilissima) melalui proses pematangan dengan penggunaan pengontrol suhu," Jurnal Universitas Brawijaya, pp. 56-66, 2013.

[8] A. H. Saptadi, "Perbandingan Akurasi Pengukuran Suhu dan Kelembaban Antara Sensor DHT11 dan DHT22 Studi Komparatif pada Platform ATMEL AVR dan Arduino," Jurnal Infotel, pp. 49-56, 2014.

[9] Susanti MN, Arianto R, Siregar RR. Embedded System Practicum Module for Increase Student Comprehension of Microcontroller. TELKOMNIKA. 2018 Feb 1;16(1):53-60. 